\title{
Organic silicon protects human neuroblastoma SH-SY5Y cells against hydrogen peroxide effects
}

\author{
Alba Garcimartín ${ }^{1,2^{*}}$, José J Merino ${ }^{3}$, Maria Pilar González ${ }^{3}$, Maria Isabel Sánchez-Reus ${ }^{3}$, Francisco J Sánchez-Muniz², \\ Sara Bastida ${ }^{2}$ and Juana Benedí ${ }^{1}$
}

\begin{abstract}
Background: Hydrogen peroxide $\left(\mathrm{H}_{2} \mathrm{O}_{2}\right)$ is a toxic agent that induces oxidative stress and cell death. Silicon (Si) is a biological element involved in limiting aluminium (Al) absorption with possible preventive effects in Alzheimer's disease. However, Si has not yet been associated with other neuroprotective mechanisms.

Methods: The present experiments evaluated in the SH-SY5Y human neuroblastoma cell line the possible role of different Si G5 (50-1000 ng/mL) concentrations in preventing cellular death induced by $\mathrm{H}_{2} \mathrm{O}_{2}(400 \mu \mathrm{M}, 24$ hours).

Results: Our findings showed that $\mathrm{H}_{2} \mathrm{O}_{2}$ promoted cell death in the human $\mathrm{SH}-\mathrm{SY} 5 \mathrm{Y}$ cell cultures and this could be prevented by $\mathrm{Si}$ treatment. The loss in cell viability mediated by $\mathrm{H}_{2} \mathrm{O}_{2}$ was due to an apoptotic and necrotic process. Apoptotic death was incurred by regulating caspase- 8 activity in the extrinsic pathway. The apoptotic and necrotic cell death induced by $\mathrm{H}_{2} \mathrm{O}_{2}$ was almost totally reversed by $\mathrm{Si}(50-500 \mathrm{ng} / \mathrm{mL})$, indicating that it down-regulates both processes in $\mathrm{H}_{2} \mathrm{O}_{2}$ treated cells.

Conclusions: According to our data, $\mathrm{Si}$ is able to increase SH-SY5Y cell survival throughout partially blocking cellular damage related to oxidative stress through a mechanism that would affect $\mathrm{H}_{2} \mathrm{O}_{2} / \mathrm{ROS}$ elimination.
\end{abstract}

Keywords: Silicon, Cellular death, LDH, ROS, Caspase-3,-8,-9, Neuroprotection

\section{Background}

Silicon (Si) is a biologically important element that is soluble in water as silicic acid, $\mathrm{Si}(\mathrm{OH})_{4}$. It has been reported that $\mathrm{Si}$ is a decisive factor in limiting absorption of dietary Aluminium (Al) [1]. Si administration reduced $\mathrm{Al}$ accumulation in several tissues, including brain areas of rats orally exposed to $\mathrm{Al}[2,3]$. In the form of silicon dioxide $\left(\mathrm{SiO}_{2}\right), \mathrm{Si}$ is the most abundant element on the Earth's crust together with oxygen. Nevertheless, its biological role has not yet been well studied [4]. Si has been considered an "essential" element since chicks receiving Si-deprived diet showed poor growth [5], and because it is also necessary to assure normal growth impairment [6]. Apart from its physiological role in bone and cartilage formation, $\mathrm{Si}$ has been associated with cardiovascular protection, immune system enhancement and protective

\footnotetext{
*Correspondence: a.garcimartin@ucm.es

'Depatamento de Farmacología, Facultad de Farmacia, Universidad Complutense de Madrid, 28040 Madrid, Spain

2Departamento de Nutrición y Bromatología I (Nutrición), Facultad de Farmacia, Universidad Complutense de Madrid, 28040 Madrid, Spain Full list of author information is available at the end of the article
}

effects in the Alzheimer's disease [7,8]. Despite its numerous properties, its biological function remains unclear. Its blood concentration is similar to other elements like zinc [9] and in urine the concentration is like that of calcium, but contrary to other elements and although it is quite ubiquitous [10], it does not associate with plasma proteins [11] and does not have an identified binding site [12]. Finally, Si does not seem to take part in any biochemical reactions/interactions because it does not have bioorganicinorganic chemistry [13]. Ortho-silicic acid, or monomeric $\mathrm{Si}(\mathrm{OH})_{4}$, is water soluble and stable in highly diluted aqueous solutions. It plays a crucial role in delivering $\mathrm{Si}$ to the living organisms' cells. Thus, it represents the major source of Si for both humans and animals. The recommended daily Si intake (RDI) has not yet been set $[14,15]$. Some studies suggest that serum Si levels decrease in pregnancy [16] and with aging, particularly in women [17]; thus, supplementation with $\mathrm{Si}$ in available forms, such as organic $\mathrm{Si}$, could prevent degenerative processes. As already commented, $\mathrm{Si}$ reduces $\mathrm{Al}$ bioavailability, thereby possibly limiting $\mathrm{Al}$ neurotoxicity. Consumption 
of moderately large amounts of beer and ortho-silicic acid, in both humans and mice, reduced $\mathrm{Al}$ uptake from the digestive tract and prevented the accumulation of $\mathrm{Al}$ in the brain $[1,18]$. Silicic acid has also been found to induce down-regulation of endogenous antioxidant enzymes associated with $\mathrm{Al}$ administration and to normalize tumour necrosis factor alpha (TNF- $\alpha$ ) mRNA expression [19]. Davenward et al. [20] showed that Si-rich mineral waters can be used as a non-invasive method to reduce the body burden of $\mathrm{Al}$ in both Alzheimer's patients and a control group by facilitating the removal of $\mathrm{Al}$ via the urine without any other concomitant effect. Si has also been shown to induce clinically relevant cognitive improvements in a pilot study with 3 of 15 patients with Alzheimer's disease [20-22]. This suggests a possible use for ortho-silicic acid as long-term non-invasive therapy for $\mathrm{Al}$ reduction in Alzheimer's disease patients.

To the best of our knowledge, the effect of organic Si on oxidative stress induced by $\mathrm{H}_{2} \mathrm{O}_{2}$ pre-treatment of $\mathrm{SH}-\mathrm{SY} 5 Y$ cells has not been evaluated. The present paper hypothesized that $\mathrm{Si}$ plays a neuroprotective role against the $\mathrm{H}_{2} \mathrm{O}_{2}$ oxidative aggression by removing ROS. It has been analysed whether organic Si G5 could induces protective effects against $\mathrm{H}_{2} \mathrm{O}_{2}$ neurotoxicity in human neuroblastoma SH-SY5Y cell line. Cellular viability on the MTT assay, caspase activation (caspase-3,-8,-9) and $\mathrm{LDH}$ release were all quantified to evaluate the effects of $\mathrm{Si}$ and $\mathrm{H}_{2} \mathrm{O}_{2}$. In the present study $\mathrm{H}_{2} \mathrm{O}_{2}$ was chosen as toxic agent because: a) it is the most stable of the longlived reactive oxygen species (ROS) [23]; b) it passes through cellular membranes [24]; and c) free radicals are involved in the pathogenesis of many degenerative diseases such as Alzheimer's, Parkinson's and Multiple sclerosis [25].

\section{Methods}

\section{Reagents/materials}

Silicium organique G5 “TM” was purchased from Glycan Group (Geneva Switzerland). Dulbecco's modified Eagle's medium (DMEM), foetal bovine serum (FBS), $0.25 \%$ trypsin-EDTA, and penicillin/streptomycin mixture were obtained from GIBCO-BRL (Grand Island, NY, USA). Hydrogen peroxide $\left(\mathrm{H}_{2} \mathrm{O}_{2}\right)$, 3-(4,5-dimethyl thiazol-2-yl)2,5-diphenyltetrazoliumbromide (MTT), Ac-DEVD-AMC[N-acetyl-Asp-Glu-Val-Asp-(7-amino-4-methyl-coumarin)], Ac-LETD-AFC-[Leu-Glu-Thr-Asp-(7-amino-4-trifluoromethyl-coumarin)], Ac-LEHD-AFC-[Leu-Glu-His-Asp(7-amino-4-trifluoromethyl-coumarin)], barbituric acid, butylated hydroxytoluene (BHT),2,7-dichlorodihydrofluorescein diacetate $\left(\mathrm{H}_{2} \mathrm{DCF}-\mathrm{DA}\right)$, dimethyl sulfoxide (DMSO), DL-Dithiothreitol (DTT) and 1,1,3,3-tetramethoxypropane were purchased from Sigma Chemical Co. (St. Louis, MO, USA). Other chemicals were reactive grade products from Merck (Darmstadt, Germany).

\section{Cell culture and treatment}

Human SH-SY5Y neuroblastoma cells were grown in DMEM supplemented with $10 \%$ foetal bovine serum (FBS) and $100 \mathrm{IU} / \mathrm{ml}$ penicillin/streptomycin, maintained in a humidified atmosphere of $5 \% \mathrm{CO}_{2}$ and $95 \%$ air at $37^{\circ} \mathrm{C}$. The culture medium was removed every three days and sub-cultures were used once they reached 80$90 \%$ confluence. $24 \mathrm{~h}$ later, cells were treated in DMEM containing $1 \% \mathrm{FBS}$ in the presence/absence of organic silicon $\left(50 \mathrm{ng} / \mathrm{mL}\right.$ - 20,000 ng/mL), $\mathrm{H}_{2} \mathrm{O}_{2} 400 \mu \mathrm{M}$ or both, together and added at the same time. $\mathrm{H}_{2} \mathrm{O}_{2}$ was freshly prepared from a $30 \%$ stock solution prior to each experiment. Control cells without Si treatment were included in all experiments. Treatment was maintained for $24 \mathrm{~h}$ except in the experiment of ROS measurement in which cells were treated for only $2 \mathrm{~h}$.

\section{Protein estimation}

The protein concentrations of cell extracts were determined by the Bradford [26] method using bovine serum albumin as standard.

\section{MTT assay}

This assay is based on the ability of living metabolically active cells to reduce the MTT, a soluble formazan salt, given a purple colour. Therefore, the conversion only occurs in living cells. The MTT assay provides a sensitive measurement of the metabolic status of cells and is used to evaluate cell viability. SH-SY5Y were seeded into 96well culture plates $\left(3 \times 10^{4}\right.$ cells/well) and allowed to attach. After the above treatment MTT, solution $(2 \mathrm{mg} / \mathrm{mL})$ was added to each well and incubated in the dark for 1 hour at $37^{\circ} \mathrm{C}$. Supernatants were removed, blue formazan crystals were dissolved in DMSO and absorbance at $595 \mathrm{~nm}$ was measured with a microplate reader (LT-4000, Labtech International Ltd, United Kingdom). All MTT assays were performed in quadruplicate. The results are expressed as the percentage of MTT reduction relative to control cells.

\section{$\mathrm{LDH}$ release measurement}

Intracellular enzyme lactate dehydrogenase is released into the cell culture medium when cell membrane damage occurs. LDH release is a good marker to detect necrosis. Enzyme activity was determined by spectrophotometric assay according to López et al. [27]. Briefly, NADH oxidation produces a decrease in the absorbance at $340 \mathrm{~nm}$, and this was measured to determined LDH activity by the following formula:

$$
\text { Pyruvate }+\mathrm{NADH} \stackrel{\mathrm{LDH}}{\longrightarrow} \text { Lactate }+\mathrm{NAD}^{+}
$$

SH-SY5Y cells $\left(3 \times 10^{5}\right.$ cells/well in 24 -well plates $)$ were treated and incubated $24 \mathrm{~h}$ at $37^{\circ} \mathrm{C}$. Culture medium from all samples was collected. In addition, the cells 
were homogenized with $0.1 \mathrm{M} \mathrm{KH}_{2} \mathrm{PO}_{4} / \mathrm{K}_{2} \mathrm{HPO}_{4}(\mathrm{pH}$ 7.4), containing $0.1 \%$ Triton X-100. Cells homogenates were centrifuged at 13,000 g for $10 \mathrm{~min}$. LDH activity was measured both in cell supernatant as well as in the culture medium. Activity of the LDH release is expressed as percentage with respect to the total LDH content (LDH in the supernatant $+\mathrm{LDH}$ inside the cells) according to the following formula:

$\% \mathrm{LDH}$ release $=(\mathrm{LDH}$ activity in the medium $\times 100) /$ total LDH activity

Measurement of reactive oxygen species (ROS) formation To assay ROS formation, 2,7-dichlorodihydrofluorescein diacetate $\left(\mathrm{H}_{2} \mathrm{DCF}-\mathrm{DA}\right)$, a non-fluorescent lipophilic reagent, was used. $\mathrm{H}_{2}$ DCF-DA enters cells, where it is transformed into 2,7-dichlorodihydrofluorescein $\left(\mathrm{H}_{2} \mathrm{DCF}\right)$ by the action of intracellular stearases. $\mathrm{H}_{2} \mathrm{DCF}$ is oxidized to fluorescent DCF by $\mathrm{H}_{2} \mathrm{O}_{2} \cdot \mathrm{H}_{2}$ DCF-DA $(5 \mu \mathrm{M})$ was added to the cells, before subjecting the cultures to different conditions. After $30 \mathrm{~min}$ the medium was removed and the cells were treated with $\mathrm{Si}$ or/and $\mathrm{H}_{2} \mathrm{O}_{2}$ dissolved in glucose PBS for only $15 \mathrm{~min}$. The fluorescence was measured every 15 min during $2 \mathrm{~h}$ in an FL600-BioTek spectrofluorometer (Bio-Tek Instruments INC, Germany) with filters of $485 / 20 \mathrm{~nm}$ excitation and 528/20 nm emission. Results are expressed as arbitrary fluorescence units (AFU).

\section{Lipid peroxidation assay}

Lipid peroxidation was estimated by measuring thiobarbituric acid reactive substances (TBARS) after addition of BHT as antioxidant [28]. Cells were normally treated and the extract was prepared with a lysis buffer $(0.1 \mathrm{M}$ $\mathrm{KH}_{2} \mathrm{PO}_{4} / \mathrm{K}_{2} \mathrm{HPO}_{4}(\mathrm{pH}$ 7.4), containing $0.1 \%$ Triton X-100). Briefly, the mixture including $500 \mu \mathrm{L}$ cell extract, BHT $(0.01 \%)$, phosphoric acid $(1 \% \mathrm{v} / \mathrm{v})$ and barbituric acid $(0.6 \%)$ was incubated at $100^{\circ} \mathrm{C}$ for $45 \mathrm{~min}$. After cooling, $200 \mu \mathrm{L}$ of the mixture was read at $485 / 20 \mathrm{~nm}$ excitation and 528/20 nm emission wavelengths in a fluorescence plate-reader (FL800, Bio-Tek Instruments INC, Germany). Quantification was performed with a standard curve of malondialdehyde (MDA) generated by an acid hydrolysis of 1,1,3,3- tetramethoxypropane.

\section{Caspase $-3,-8$ and -9 activity measurements}

SH-SY5Y cells were seeded into 24-well culture plates $\left(3 \times 10^{5}\right.$ cells/well). $24 \mathrm{~h}$ after treatment cells were lysed with lysis buffer $\left(10 \mathrm{mM}\right.$ Tris- $\mathrm{HCl}, 10 \mathrm{mM} \mathrm{NaH} \mathrm{PO}_{4} /$ $\mathrm{Na}_{2} \mathrm{HPO}_{4}, \mathrm{pH} 7.5,130 \mathrm{mM} \mathrm{NaCl}, 0.5 \%$ Triton X-100, $10 \mathrm{mM} \mathrm{Na} 4 \mathrm{P}_{2} \mathrm{O}_{7}$ and $2 \mathrm{mM} \mathrm{DTT}$ ) and centrifuged at $13,000 \mathrm{~g}$ for $5 \mathrm{~min}$. Caspase-3 activity was measured in the supernatants. Supernatants with at least $20 \mu \mathrm{g}$ of protein were incubated at $37^{\circ} \mathrm{C}$ for 1 to 6 hours in caspase- 3 assay buffer ( $20 \mathrm{mM}$, HEPES, $\mathrm{pH} 7.5$, with $2 \mathrm{mM} \mathrm{DTT}$ ) and $20 \mathrm{mM}$ Ac-DEVD-AMC [ $\mathrm{N}$-acetylAsp-Glu-Val-Asp-(7-amino-4-methyl-coumarin)]. Fuorochrome 7-amino-4-methyl-coumarin (AMC) is released from the substrate Ac-DEVD-AMC after reacting with caspase- 3 enzyme. The fluorescence signal produced by free AMC is proportional to the caspase- 3 activity present in the sample, for at least the first $10 \mathrm{~h}$, and this was monitored using a fluorescence plate-reader (FL800, Bio-Tek Instruments INC, Germany) at 360/40 nm excitation and 460/20 nm emission wavelengths. Enzymatic activity is expressed as arbitrary fluorescence unit after $1 \mathrm{~h}$ per $\mathrm{mg}$ protein (AFU/h/mg protein).

Caspase- 8 and -9 activities were measured as caspase- 3 but using their selective substrates (Ac-LETD-AFC-[Leu-GluThr-Asp-(7-amino-4-trifluoromethyl-coumarin)] for caspase8 and Ac-LEHD-AFC-[Leu-Glu-His-Asp-(7-amino-4-trifluoromethyl-coumarin)] for caspase-9. The fluorochrome released is 7-amino-4-trifluoromethyl-coumarin (AFC), and was measured at 360/40 $\mathrm{nm}$ excitation and 530/25 nm emission wavelengths.

\section{Evaluation of the TNF- $a$}

Release of TNF- $\alpha$ was measured in culture medium after $24 \mathrm{~h}$ of treatment using enzyme-linked immunoabsorbent assay (ELISA) (Human TNF- $\alpha$ ELISA Kit, 950.090.096, Diaclone, France) according to the manufacturer's manual. The increase in colour intensity was evaluated at $450 \mathrm{~nm}$ using a microplate reader (LT-4000, Labtech International Ltd, Acorn House, East Sussex, United Kingdom).

\section{Statistical analysis}

Data are shown as mean \pm SEM from either two or four independent experiments using different cultures, each experiment performed in triplicate with different cell batches (total 6-12 measurement/condition). Statistical analyses were made with a One-way ANOVA followed by multiple comparisons when the $\mathrm{P}$ value was significant. The Dunn's test was chosen because there were at least six different values per group. A value of $\mathrm{p}<0.05$ was considered statistically significant. Statistical analyses were performed using Sigma Plot 11.0 software.

\section{Results}

\section{Action of Si in cell viability}

Cells exposed to $400 \mu \mathrm{M} \mathrm{H} \mathrm{H}_{2} \mathrm{O}_{2}$ during $24 \mathrm{~h}$ showed a significant of decreased (40\%) cellular viability. This decline was, in part, reversed by Si G5 at concentrations ranging from 200 to $1000 \mathrm{ng} / \mathrm{mL}$ (Figure 1). The lack of a $40 \%$ cellular viability induced by $\mathrm{H}_{2} \mathrm{O}_{2}$ in the MTT assay could reflect two events: 1) cellular death or 2) loss of metabolic ability. In order to check these options, LDH release, which measures necrotic death and caspase- 


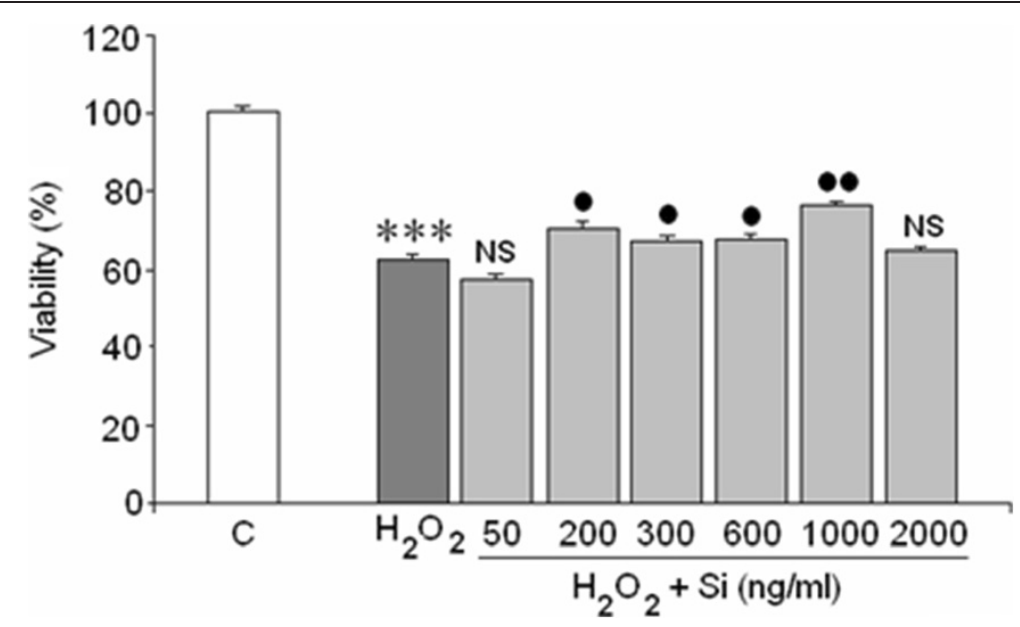

Figure 1 Effect of $\mathrm{H}_{2} \mathrm{O}_{2}$ in absence/presence of silicon (Si) G5. Results are expressed as means \pm SEM of two experiments from different cultures, each one performed in quadruplicate with different batches of cells (total 8 measurements/condition). $\left({ }^{*}\right)=$ Statistical significances are referred to the basal values. $\left(^{* * *}\right)=\mathrm{p}<0.001$. (•)/NS Statistical significances between $\mathrm{H}_{2} \mathrm{O}_{2}$ in absence and presence of silicon $\mathrm{G} 5$. NS $=$ non significant, $(\bullet)=p<0.05$ and $(\bullet \bullet)=p<0.01$.

3 increase (sensors of apoptosis), were quantified under our experimental conditions.

\section{LDH assay}

Results from Figure 2 show that adding $400 \mu \mathrm{M}$ of $\mathrm{H}_{2} \mathrm{O}_{2}$, to the cells culture for $24 \mathrm{~h}$, induced significant $(\mathrm{p}<0.001$ ) increase of LDH release. This release was partially reversed by Si G5 in a dose dependent manner at concentrations ranging from 50 to $500 \mathrm{ng} / \mathrm{mL}$ but never returned to basal values. The highest $\mathrm{Si}$ concentration tested $(750 \mathrm{ng} / \mathrm{mL})$ had no effect on necrotic death mediated by $\mathrm{H}_{2} \mathrm{O}_{2}$ in this human neuroblastoma cell line.

Since necrotic death can be a consequence of lipid peroxidation and ROS production, both markers were also evaluated.

\section{Action of Si on ROS formation}

Results from Figure 3 demonstrate that Si totally removed ROS from neuroblastoma cells treated with $400 \mu \mathrm{M} \mathrm{H}_{2} \mathrm{O}_{2}$.

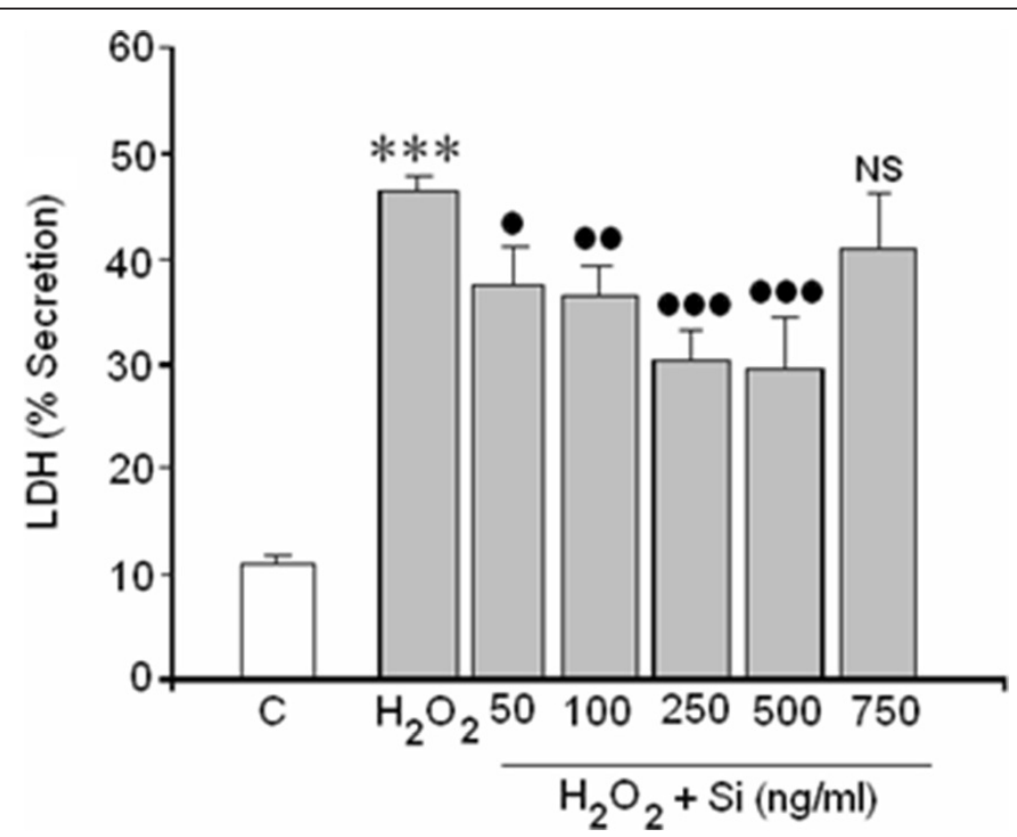

Figure 2 Effect of Si on LDH release mediated by $\mathbf{H}_{2} \mathrm{O}_{2}$. $\left.{ }^{*}\right)$ Statistical significances are referred to the basal values. $\left(^{* *}\right)=p<0.001,(\bullet) / \mathrm{NS}=$ Statistical significances between $\mathrm{H}_{2} \mathrm{O}_{2}$ in absence and presence of silicon G5. NS = non significant, $(\bullet)=p<0.05$ and $(\bullet \bullet)=p<0.01 .(\bullet \bullet \bullet)=p<0.001$. 


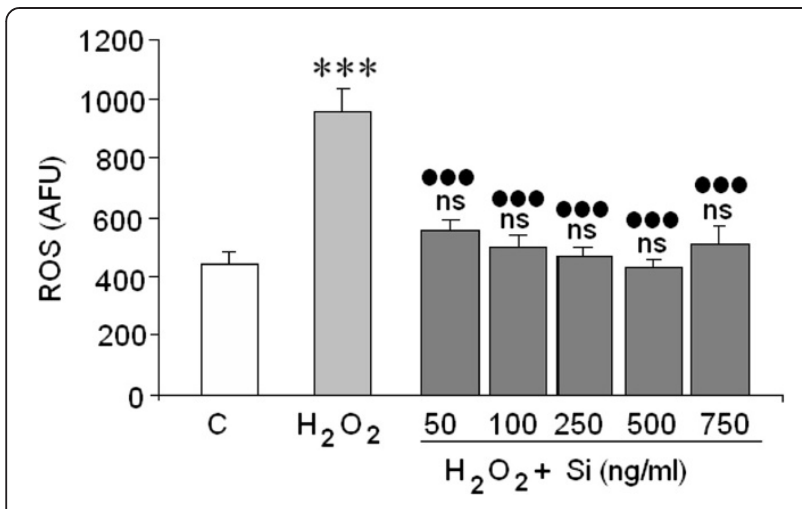

Figure 3 Effect of $\mathrm{Si}$ on $\mathrm{H}_{2} \mathrm{O}_{2}(\mathrm{ROS}) .\left({ }^{*}\right) / \mathrm{ns}=$ Statistical significances are referred to the basal values. ns $=$ no significant, $\left({ }^{* *}\right)=p<0.001,(\bullet)$ = Statistical significances between $\mathrm{H}_{2} \mathrm{O}_{2}$ in absence and presence of silicon G5. $(\bullet \bullet \bullet)=p<0.001$.

Effect of Si on lipid peroxidation mediated by $\mathrm{H}_{2} \mathrm{O}_{2}$ $400 \mu \mathrm{M} \mathrm{H}_{2} \mathrm{O}_{2}$ increased two-fold lipid peroxidation in the human neuroblastoma cell line (SH-SY5Y). Si at $250 \mathrm{ng} /$ $\mathrm{mL}$ reduced the $\mathrm{H}_{2} \mathrm{O}_{2}$ mediated lipid peroxidation to a great extent (Figure 4). However, higher concentrations of $\mathrm{Si}(750 \mathrm{ng} / \mathrm{mL})$ strongly induced lipid peroxidation which reached values higher than with $\mathrm{H}_{2} \mathrm{O}_{2}$.

\section{Si action on death mediated by caspase- 3}

Once it was found that $\mathrm{H}_{2} \mathrm{O}_{2}$ could induce cellular death through necrosis, the possibility that $\mathrm{H}_{2} \mathrm{O}_{2}$ could also induce cell death through apoptosis was analysed. Figure 5 shows $\mathrm{H}_{2} \mathrm{O}_{2}$ was a potent apoptotic inductor in the $\mathrm{SH}$ SY5Y cell line. Interestingly, Si G5 at concentrations ranging from 250 to $750 \mathrm{ng} / \mathrm{mL}$ almost totally reversed the caspase- 3 activity that had been increased by $\mathrm{H}_{2} \mathrm{O}_{2}$.

Since caspase- 3 can be activated through intrinsic as well as extrinsic pathways, caspase- 9 activity (activated by mitochondrial dysfunction), as well as caspase- 8 (activated through death receptors) were tested in the present study.

\section{Action of $\mathrm{H}_{2} \mathrm{O}_{2}$ on caspase- 9 activity}

Caspase- 9 is activated by mitochondrial dysfunction through the release of cytochrome-c which binds to cytosolic protein (Apaf-1) and procaspase-9. In the presence of ATP, a complex that converts inactive procaspase- 9 to active caspase- 9 is formed. No caspase- 9 activation could be observed in the $\mathrm{H}_{2} \mathrm{O}_{2}$-exposed $\mathrm{SH}-\mathrm{SY} 5 \mathrm{Y}$ cell culture (data not shown).

\section{Effect of $\mathrm{Si}$ on $\mathrm{H}_{2} \mathrm{O}_{2}$-mediated caspase-8 activity}

Figure 6 shows that exposure to $400 \mu \mathrm{M}$ of $\mathrm{H}_{2} \mathrm{O}_{2}$ during $24 \mathrm{~h}$ further induced caspase- 8 activation in the $\mathrm{SH}$ SY5Y culture. Si G5, at concentrations between 100 to $750 \mathrm{ng} / \mathrm{mL}$, completely reversed this $\mathrm{H}_{2} \mathrm{O}_{2}$ - mediated effect, and reduced caspase- 8 to lower than basal levels.

\section{Effects on TNF-a}

Since caspase- 8 activation is mediated though death receptor activation, TNF- $\alpha$ levels were measured by ELISA in $\mathrm{H}_{2} \mathrm{O}_{2}$ treated cells. There was not measurable TNF- $\alpha$ release mediated by $\mathrm{H}_{2} \mathrm{O}_{2}$ (data not shown).

\section{Discussion}

$\mathrm{H}_{2} \mathrm{O}_{2}$ is a classic ROS that is normally produced in cells, including neurons $[29,30]$ and thus, it has been considered an appropriate molecule to study the possible protector effect of $\mathrm{Si}$ under cell death conditions in the human neuroblastoma SH-SY5Y cell line.

Our data clearly demonstrate that $\mathrm{H}_{2} \mathrm{O}_{2}$ induced a great cell viability lost (by about $40 \%$ ), in agreement with Chetsawang et al. [31] who found SH-SY5Y cells loss viability mediated by $\mathrm{H}_{2} \mathrm{O}_{2}$. Those authors suggest that Ras protein could be involved in this cell survival decrease.

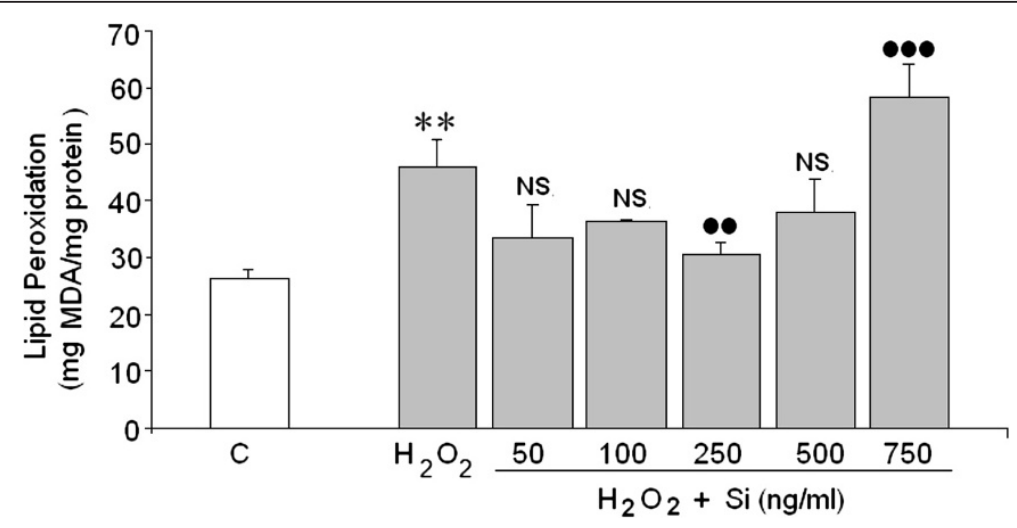

Figure 4 Effect of Si on lipid peroxidation. $\left(^{*}\right)=$ Statistical significances are referred to the basal values. ns $=$ no significant, $\left({ }^{* *}\right)=p<0.01$, $(\bullet) / \mathrm{NS}=$ Statistical significances between $\mathrm{H}_{2} \mathrm{O}_{2}$ in absence and presence of silicon G5. NS = non significant, $(\bullet \bullet)=p<0.01 .(\bullet \bullet \bullet)=p<0.001$. 


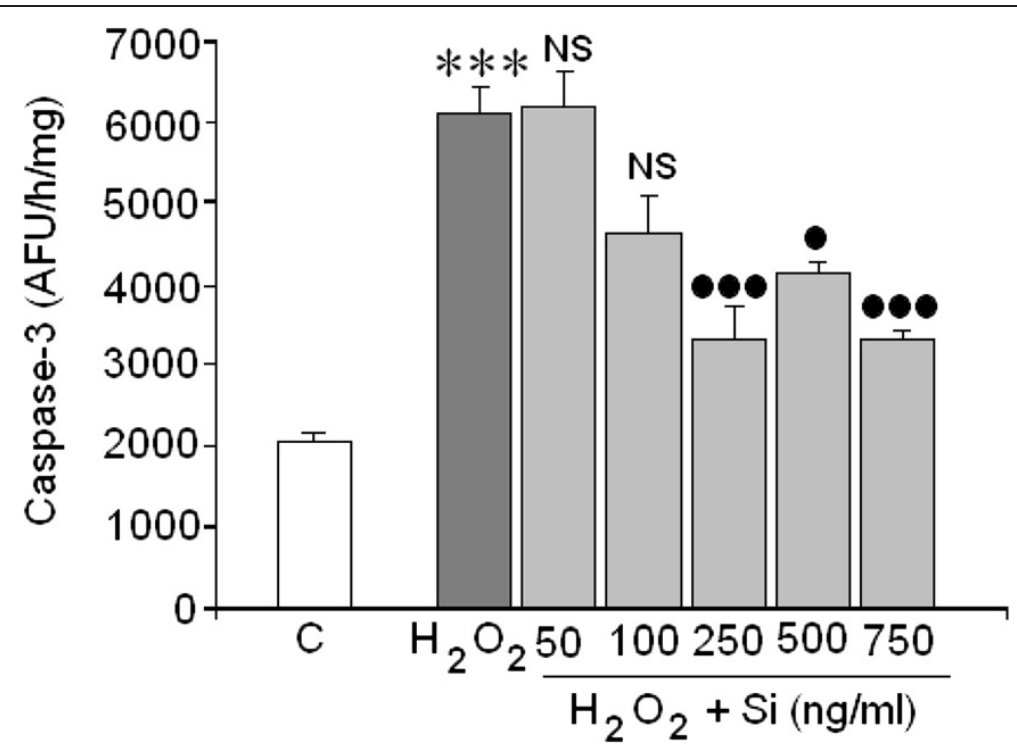

Figure 5 Action of Si on caspase-3 activation mediated by $\mathrm{H}_{2} \mathrm{O}_{2} \cdot\left({ }^{*}\right)=$ Statistical significances referred to the basal values. $\left({ }^{* * *}\right)=p<0.001$. $(\bullet) / N S=$ Statistical significances between $\mathrm{H}_{2} \mathrm{O}_{2}$ in absence and presence of silicon G5. $(\bullet)=p<0.05$ and $(\bullet \bullet \bullet)=p<0.001$.

However, Si levels ranging 200 to $1000 \mathrm{ng} / \mathrm{mL}$ increased cell survival, confirming our hypothesis that $\mathrm{Si}$ can alleviate $\mathrm{H}_{2} \mathrm{O}_{2}$ neurotoxicity. At higher Si concentration $(2000 \mathrm{ng} / \mathrm{mL})$ did not protect cellular viability and this could be because Si may be toxic at high concentrations. Toxicity from high $\mathrm{Si}$ concentrations has been suggested by several researchers [32,33]. Neuronal cell death by apoptosis induced by oxidative stress has already been reported [34] but acute oxidative stress also often induces necrotic outcomes [35].
Oxidative stress, produced by excess ROS, is considered to be the major contributor to cell death in several CNS pathologies [36] such as Parkinson's disease [37] and Alzheimer's disease [38] or cerebral ischemia reperfusion after stroke $[39,40]$. Since ROS may induce apoptosis or necrosis depending on the level of intracellular ROS and ATP levels [41], the mechanism by which $\mathrm{H}_{2} \mathrm{O}_{2}$ induces cellular death and the possible protector effects of $\mathrm{Si}$ against both types of cell death requires study. The results showed that the loss of cell viability

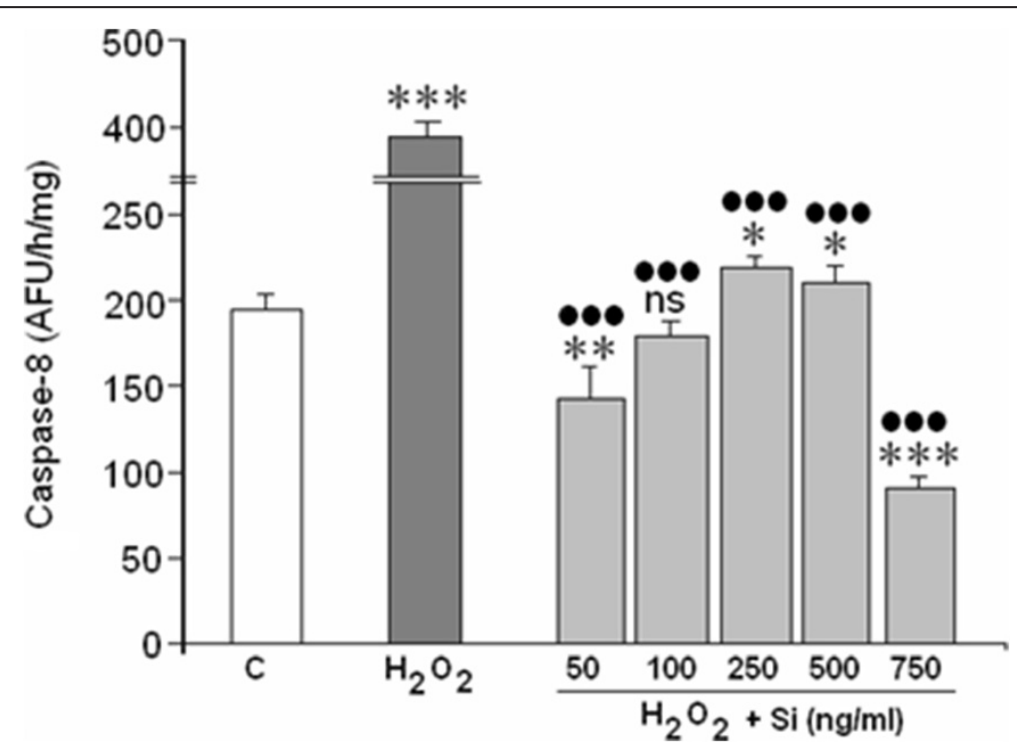

Figure 6 Action of Si on caspase-8 activation mediated by $\mathrm{H}_{2} \mathrm{O}_{2} \cdot\left({ }^{*}\right) / \mathrm{ns}=$ Statistical significances referred to the basal values. ns $=$ no significant, $\left({ }^{*}\right)=\mathrm{p}<0.05,\left(^{* *}\right)=\mathrm{p}<0.01$ and $\left({ }^{* *}\right)=\mathrm{p}<0.001 .(\bullet)=$ Statistical significances between $\mathrm{H}_{2} \mathrm{O}_{2}$ in absence and presence of silicon $\mathrm{G} 5 .(\bullet \bullet \bullet)=\mathrm{p}<0.001$. 
induced by $\mathrm{H}_{2} \mathrm{O}_{2}$ in the SH-SY5Y was the result of both necrosis and apoptosis (Figure 7). With regard to the necrosis, $\mathrm{H}_{2} \mathrm{O}_{2}$ increased LDL release 4.5 times. $\mathrm{Si}$, doses of 50 to $500 \mathrm{ng} / \mathrm{mL}$, reversed the $\mathrm{H}_{2} \mathrm{O}_{2}$ induced LDH release on a great extent. However, the highest concentration of $\mathrm{Si}(750 \mathrm{ng} / \mathrm{mL})$ employed did not exert any significant effect on cell necrosis death although it did reduce the caspase- 3 activation. The protective effect of $\mathrm{Si}$ against $\mathrm{H}_{2} \mathrm{O}_{2}$ toxicity might be a consequence of its capacity to remove $\mathrm{ROS}$ because $\mathrm{Si}$ at doses ranging from 50 to $500 \mathrm{ng} / \mathrm{mL}$ completely prevented the ROS increase in $\mathrm{H}_{2} \mathrm{O}_{2}$ treated cells.

Moreover, regarding apoptotic death, $\mathrm{H}_{2} \mathrm{O}_{2}$ produced caspase-3 activation in the treated SH-SY5Y cells. This activation was not mediated via the mitochondria pathway but through the death receptors because caspase- 8 but not caspase- 9 was activated by $\mathrm{H}_{2} \mathrm{O}_{2}$. Effects of $\mathrm{H}_{2} \mathrm{O}_{2}$ as inductor of apoptosis or necrosis have been described in different cell types [42-45]. Generally, ROSmediated apoptosis is linked to the intrinsic pathway through Bax activation, which aggregates into mitochondria and leads to cytochrome-c release. Consequently, this event activates caspase-9 which finally leads to caspase- 3 activation. However, in our case we found no caspase-9 activation. On the other hand, apoptosis mechanisms acting through the extrinsic pathway have also been described in HeLa cells treated with different $\mathrm{H}_{2} \mathrm{O}_{2}$ concentrations for $8 \mathrm{~h}$. Since apoptosis, via the extrinsic pathway, is mediated through death receptors, the possible involvement of TNF- $\alpha$ in cell death was investigated in our study. The results suggested that $\mathrm{H}_{2} \mathrm{O}_{2}$ was not able to increase TNF- $\alpha$ release under our experimental conditions. Nonetheless, this result does not mean that activation of caspase- 8 cannot be mediated by death receptors other than TNF- $\alpha$, such as Fas, TRAS, or DR4,5, which would probably also be involved. In this way, Medan et al. [46] reported that $\mathrm{H}_{2} \mathrm{O}_{2}$ and hydroxyl radical $\left(\mathrm{OH}^{*}\right)$ were key mediators of apoptosis in macrophages, increasing FasL; and Wang et al. [47], using an elegant approximation to study the ROS species responsible for the implication of FasL in apoptosis induction, demonstrated that $\mathrm{H}_{2} \mathrm{O}_{2}$ and $\mathrm{O}_{2}{ }^{--}$were the ROS species that were most involved in this process.

As a whole, our findings suggest that $\mathrm{H}_{2} \mathrm{O}_{2}$ induction of cellular death may be explained according to the scheme in Figure $7 . \mathrm{H}_{2} \mathrm{O}_{2}$, by an unknown mechanism, perhaps induction of a death ligand, that would activate the death receptor responsible to activate caspase -8 (inductor enzyme) which activates caspase -3 (effector enzyme). This last enzyme would damages DNA and protein and as a consequence, produces apoptosis. On the other hand, $\mathrm{H}_{2} \mathrm{O}_{2}$ induces lipid peroxidation, which conduces to LDH release and necrosis death. In the presence of $\mathrm{Si}$, treated cells seem to remove $\mathrm{H}_{2} \mathrm{O}_{2}$ (ROS), preventing the neurotoxicity induced by $\mathrm{H}_{2} \mathrm{O}_{2}$. Taken together these neuroprotective effects from $\mathrm{Si}$ could suggest

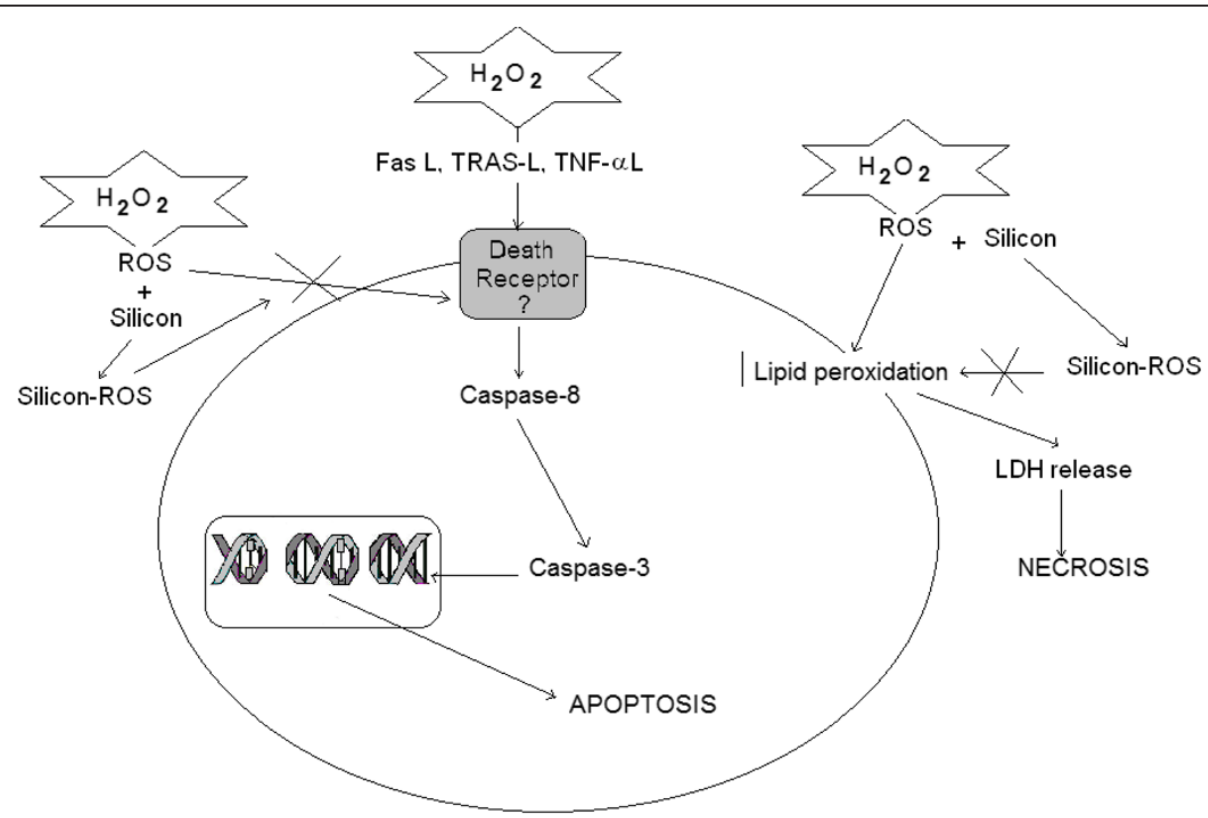

Figure 7 Diagram of the mechanism by which both $\mathrm{H}_{2} \mathrm{O}_{2}$ and $\mathrm{Si}$ induce cellular damage and neuroprotection. $\mathrm{H}_{2} \mathrm{O}_{2}$ inducing apoptosis: $\mathrm{H}_{2} \mathrm{O}_{2}$, perhaps, by induction of death ligand, may activate death receptor responsible to activate caspase-8 (inductor enzyme) which activates caspase-3 (effectors enzyme). This last enzyme damages DNA and protein and as consequence produces apoptosis. $\mathrm{H}_{2} \mathrm{O}_{2}$ inducing necrosis: $\mathrm{H}_{2} \mathrm{O}_{2}$ (ROS) induces lipid peroxidation which conduces to LDH release and necrosis death. Si effect: In the presence of $\mathrm{Si}, \mathrm{H}_{2} \mathrm{O}_{2}$ treated cells remove $\mathrm{H}_{2} \mathrm{O}_{2}$ (ROS) preventing neurotoxicity induced by it. 
a preventive role for $\mathrm{Si}$ in the context of neurodegenerative disease, including Alzheimer's disease.

\section{Conclusions}

1. - Oxidative stress promoted by $\mathrm{H}_{2} \mathrm{O}_{2}$ induces cellular death through two mechanisms: apoptosis and necrosis.

2. - Apoptosis mediated by $\mathrm{H}_{2} \mathrm{O}_{2}$ acts through the extrinsic pathways since caspase- 8 is involved without affecting caspase -9 activation in $\mathrm{H}_{2} \mathrm{O}_{2}$ treated human neuroblastoma cells.

3. - Si G5 protects, to a great extent, against both cellular death mechanism in the human SH-SY5Y in the presence of $\mathrm{H}_{2} \mathrm{O}_{2}$.

4. - ROS removal seems a principal mechanism of Si to protect $\mathrm{SH}-\mathrm{SY} 5 \mathrm{Y}$ cell line against oxidative stress mediated by $\mathrm{H}_{2} \mathrm{O}_{2}$.

As a whole, these mechanisms suggest that Si G5 could be a neuroprotective agent that would help prevent cell death under vulnerability conditions associated to strong ROS production.

\section{Abbreviations}

AFC: 7-amino-4-trifluoromethyl-coumarin; Al: Aluminium; AMC: Fluorochrome 7-amino-4-methyl coumarin; BHT: Butylated hydroxytoluene; $\mathrm{H}_{2}$ DCF-DA: 2,7-dichlorodihydrofluorescein diacetate; DMEM: Dulbecco's modified Eagle's medium; DMSO: Dimethyl sulfoxide; DTT: Dithiothreitol; FBS: Foetal bovine serum; $\mathrm{H}_{2} \mathrm{O}_{2}$ : Hydrogen peroxide; LDH: Lactate dehydrogenase; MDA: Malondialdehyde; MTT: 3-(4,5-dimethyl thiazol-2-yl)-2,5-diphenyltetrazoliumbromide; Si: Silicon; $\mathrm{SiO}_{2}$ : Silicon dioxide; ROS: Reactive oxygen species;

TBARS: Thiobarbituric acid reactive substances.

\section{Competing interest}

There are no conflicts of interests. The authors declare that they have no competing financial interest. All authors only work in basic research and official Scientific Institutions.

\section{Authors' contributions}

AG and MPG carried out the experiments, participated in data analysis and drafted the manuscript. JJM, performed the statistical analysis and helped to review the manuscript. FJSM and JB participated in its design and coordination. MISR and SB helped to review the manuscript. All authors read and approved the final manuscript.

\section{Acknowledgments}

The present study was supported by the Spanish project AGL2011-29644C02-02. We acknowledge the predoctoral fellowship granted to Alba Garcimartín by BES-2012-054752 (FPI).

\section{Author details}

'Depatamento de Farmacología, Facultad de Farmacia, Universidad Complutense de Madrid, 28040 Madrid, Spain. ²Departamento de Nutrición y Bromatología I (Nutrición), Facultad de Farmacia, Universidad Complutense de Madrid, 28040 Madrid, Spain. ${ }^{3}$ Departamento de Bioquímica y Biología Molecular II, Facultad de Farmacia, Universidad Complutense de Madrid, 28040 Madrid, Spain.

Received: 30 June 2014 Accepted: 29 September 2014 Published: 8 October 2014

\section{References}

1. Edwardson JA, Moore PB, Ferrier IN, Lilley JS, Newton GW, Barker J, Templar J, Day JP: Effect of silicon on gastrointestinal absorption of aluminum. Lancet 1993, 342:211-212.

2. Carlisle EM, Curran MJ: Effect of dietary silicon and aluminum on silicon and aluminum levels in rat brain. Alzheimer Dis Assoc Disord 1987, 1:83-89.

3. Bellès M, Sanchez DJ, Gómez M, Corbella J, Domingo JL: Silicon reduces aluminum accumulation in rats: relevance to the aluminum hypothesis of Alzheimer's disease. Alzheimer Dis Assoc Disord 1998, 12:83-87.

4. Greenwood NN, Earnshaw A: Chemistry of the Elements. 2nd edition. Oxford: Butterworth-Heinemann; 1997.

5. Carlisle EM: Silicon: an essential element for the chick. Science 1972, 178:619-621.

6. Schwarz K, Milne DB: Growth promoting effects of silicon in rats. Nature 1972, 239:333-334.

7. Candy JM, Edwardson JA, Klinowski J, Oakley AE, Perry EK, Perry RH: Colocalisation of Aluminum and Silicon in Senile Plaques: Implications for the Neurochemical Pathology of Alzheimer's Disease. In Senile Dementia of the Alzheimer Type. Edited by Traber J, Gispen WH. Heidelberg: Springer; 1985:183-197.

8. Jurkić LM, Cepanec I, Pavelić KS, Pavelić K: Biological and therapeutic effects of ortho-silicic acid and some ortho-silicic acid-releasing compounds: new perspectives for therapy. Nutr Metab 2013, 10:1-12.

9. Dobbie JW, Smith MJB: The silicon content of body fluids. Scott Med J 1982, 27:17-19.

10. Dobbie JW, Smith MJB: Silicon: its role in medicine and biology. Scott Med J 1982, 27:1-2.

11. D'Haese PC, Shaheen FA, Huraib SO, Djukanovic L, Polenakovic MH, Spasovski G, Shikole A, Schurgers ML, Daneels RF, Lamberts LV, Van Landeghem GF, De Broe ME: Increased silicon levels in dialysis patients due to high silicon content in the drinking water, inadequate water treatment procedures, and concentrate contamination: a multicentre study. Nephrol Dial Transplant 1995, 10:1838-1844.

12. Perry CC, Keeling-Tucker T: Aspects of the bioinorganic chemistry of silicon in conjunction with the biometals calcium, iron and aluminium. $J$ Inorg Biochem 1998, 69:181-191.

13. Exley C: Darwin, natural selection and the biological essentiality of aluminium and silicon. Trends Biochem Sci 2009, 34:589-593.

14. Scientific Committee for Food: Nutrient and Energy Intakes for the European Community, Reports of the Scientific Committee for Food (Thirty-first series). Luxembourg: European Commission; 1993.

15. European Food Safety Authority: Opinion of the scientific panel on dietetic products, nutrition and allergies on a request from the commission related to the tolerable upper intake level of silicon. EFSA J 2004, 60:1-11.

16. Van Dyck K, Robberecht H, Van Cauwenbergh R, Van Vlaslaer V, Deelstra H: Indication of silicon essentiality in humans. serum concentrations in Belgian children and adults including pregnant women. Biol Trace Elem Res 2000, 77:25-32.

17. Bissé E, Epting $T$, Beil A, Lindinger $G$, Lang $H$, Wieland $H$ : Reference values for serum silicon in adults. Anal Biochem 2005, 337:130-135.

18. González-Muñoz MJ, Meseguer I, Sanchez-Reus MI, Schultz A, Olivero R, Benedi J, Sánchez-Muniz FJ: Beer consumption reduces cerebral oxidation caused by aluminum toxicity by normalizing gene expresión of tumor necrotic alpha and several antioxidant enzymes. Food Chem Toxicol 2008, 46:1111-1118.

19. Candy JM, Oakley AE, Klinowski J, Carpenter TA, Perry EK, Blessed G, Fairbairn A, Edwardson JA: Aluminosilicates and senile plaque formation in Alzheimer's disease. Lancet 1986, 1:354-357.

20. Davenward S, Bentham P, Wright J, Crome P, Job D, Polwart A, Exley C: Silicon-rich mineral water as a non-invasive test of the 'aluminum hypothesis' in Alzheimer's disease. J Alzheimers Dis 2013, 33:423-430.

21. Miu AC: The silicon link between aluminium and Alzheimer's disease. J Alzheimers Dis 2006, 10:39-42.

22. Rondeau V, Jacamin-Gadda H, Commenges D, Helmer C, Dartiques JF: Aluminum and Silica in drinking water and the risk of Alzheimer's disease or cognitive cecline: findings from 15-year follow-up of the PAQUID cohort. Am J Epidemiol 2009, 169:489-496.

23. Kress M, Ried B, Reeh PW: Effects of oxygen radicals on nociceptive afferents in the rat skin in vitro. Pain 1995, 62:87-94. 
24. Waldron RT, Rozengurt E: Oxidative stress induces protein kinase D activation in intact cells. involvement of Src and dependence on protein kinase C. J Biol Chem 2000, 275:17114-17121.

25. Bayani AA: Psychometric data for a Farsi translation of the Trait MetaMood Scale. Psychol Rep 2009, 105:198-204

26. Bradford MA: Rapid sensitive method for the quantitation of microgram quantities of protein utilizing the principle of protein-dye binding. Anal Biochem 1976, 72:248-254.

27. López E, Figueroa S, Oset-Gasque MJ, González MP: Apoptosis and necrosis: two distinct events induced by cadmium in cortical neurons in culture. $\mathrm{Br} \mathrm{J}$ Pharmacol 2003, 138:901-911.

28. Mihara $M$, Uchiyama M: Determination of malonaldehyde precursor in tissues by thiobarbituric acid test. Anal Biochem 1978, 86:271-278.

29. Nagai $N$, Ito $Y$ : Excessive hydrogen peroxide enhances the attachment of amyloid $\beta 1-42$ in the lens epithelium of UPL rats, a hereditary model for cataracts. Toxicology 2014, 315:55-64.

30. Xie H, Hou S, Jiang J, Sekutowicz M, Nelly J, Bacskai BJ: Rapid cell death is precede by amyloid plaque-mediated oxidative stress. Proc Natl Acad SCi U S A 2013, 110:7904-7909.

31. Chetsawang J, Govitrapong P, Chetsawang B: Hydrogen peroxide toxicity induces ras signaling in human neuroblastoma SH-SY5Y cultured cells. J Biomed Biotechnol 2010, 2010:803815.

32. Steenland K, Ward E: Silica: a lung carcinogen. CA Cancer J Clin 2014, 64:63-69.

33. Zhou T, Rong Y, Liu Y, Zhou Y, Guo J, Cheng W, Wang H, Chen W: Association between proinflammatory responses of respirable silica dust and adverse health effects among dust-exposed workers. J Occup Environ Med 2012, 54:459-465.

34. Valencia A, Moran J: Reactive oxygen species induce different cell death mechanisms in cultured neurons. Free Radic Biol Med 2004, 36:1112-1125.

35. Fatokun AA, Stone TW, Smith RA: Adenosine receptor ligands protect against a combination of apoptotic and necrotic cell death in cerebellar granule neurons. Exp Brain Res 2008, 186:151-160.

36. Uttara B, Singh AV, Zamboni P, Mahajan RT: Oxidative stress and neurodegenerative diseases: a review of upstream and downstream antioxidant therapeutic options. Curr Neuropharmacol 2009, 7:65-74.

37. Jenner P: Oxidative stress in Parkinson's disease. Ann Neurol 2003, 53:S26-S36.

38. Pratico D: Evidence of oxidative stress in Alzheimer's disease brain and antioxidant therapy. Ann N Y Acad Sci 2008, 1147:70-78.

39. Allen $\mathrm{CL}$, Bayraktutan $\mathrm{U}$ : Oxidative stress and its role in the pathogenesis of ischemic stroke. Int J Stroke 2009, 4:461-470.

40. Merino JJ, Oset-Gasque MJ: The CXCR7 activation by SDF1 induces neural progenitor migration (NPC): a dual effect on CXCR4/CXCR7 axis within the vascular niche of ischemic rats. Int J Stroke 2013, 8:E56.

41. Ryter SW, Kim HP, Hoetzel A, Park JW, Nakahira K, Wang X, Choi AM: Mechanisms of cell death in oxidative stress. Antioxid Redox Signal 2000, 9:49-89.

42. Samuilov VD, Kiselevsky DB, Shestak AA, Nesov AV, Vasil'ev LA: Reactive oxygen species in programmed death of pea guard cells. Biochem-Moscow 2008, 73:1076-1084.

43. Sun $B$, Sun GB, Xiao J, Chen RC, Wang $X$, Wu Y, Cao L, Yang ZH, Sun XB: Isorhamnetin inhibits $\mathrm{H}_{2} \mathrm{O}_{2}$-induced activation of the intrinsic apoptotic pathway in $\mathrm{H} 9 \mathrm{c} 2$ cardiomyocytes through scavenging reactive oxygen species and ERK inactivation. J Cell Biochem 2012, 113:473-485.

44. Sui $X Q, X u Z M, X i e M B, P e i D A$ : Resveratrol inhibits hydrogen peroxideinduced apoptosis in endothelial cells via the activation of PI3K/Akt by miR-126. J Atheroscrerosc Thromb 2014, 21:108-118.

45. Okahashi N, Nakata M, Sumitomo T, Terao Y, Kawabata S: Hydrogen peroxide produced by oral Streptococci induces macrophage cell death. PLOS One 2013, 8:1-6.
46. Medan D, Wang L, Toledo D, Lu B, Stehlik C, Shi X, Rojanasakul Y: Regulation of Fas (CD95/ APO-1)-mediated apoptosis and necrosis by reactive oxygen species in macrophages. J Cell Physiol 2005, 203:78-84.

47. Wang L, Azad N, Kongkaneramit L, Chen F, Lu Y, Jiang BH, Rojanasakul Y: The Fas death signalling pathway connecting reactive oxygen species generation and FLICE inhibitory protein down-regulation. J Immunol 2008, 180:3072-3080.

doi:10.1186/1472-6882-14-384

Cite this article as: Garcimartín et al:: Organic silicon protects human neuroblastoma SH-SY5Y cells against hydrogen peroxide effects. BMC Complementary and Alternative Medicine 2014 14:384.

\section{Submit your next manuscript to BioMed Central and take full advantage of:}

- Convenient online submission

- Thorough peer review

- No space constraints or color figure charges

- Immediate publication on acceptance

- Inclusion in PubMed, CAS, Scopus and Google Scholar

- Research which is freely available for redistribution

Submit your manuscript at www.biomedcentral.com/submit
C) Biomed Central 